\title{
Mus musculus
}

National Cancer Institute

\section{Source}

National Cancer Institute. Mus musculus. NCI Thesaurus. Code C45247.

The common mouse species, Mus musculus. 